\title{
Intraspecific Karyotypical Diversity in Brackish Water Fishes of the Eleotridae Family (Pisces, Perciformes)
}

\author{
Wagner Franco Molina* \\ Departamento de Biologia Celular e Genética, Universidade Federal do Rio Grande do Norte, \\ Campus Universitário, 59078-970, Natal, RN, Brazil
}

Received October 17, 2004; accepted December 18, 2004

\begin{abstract}
Summary The Eleotridae family consists of 35 genera and 150 species distributed in freshwaters/brackish waters, estuaries or shores of tropical and subtropical regions. A few species are found in the Central America and South America. Cytogenetic analyses were performed on sympatric species Dormitator maculatus (12 individuals; 9 males and 3 females) and Eleotris pisonis (5 individuals; 2 males and 3 females) collected in the lower course of the Pium River, Northeastern Brazil. Both the species have $2 n=46$ with striking differences for the chromosome formulas $(D$. maculatus, $40 \mathrm{~m}$-sm +6 st-a and E. pisonis, $46 \mathrm{a}$ ). The two species revealed preferentially centromeric or telomeric heterochromatic regions and absence of structural chromosome heteromorphisms between the sexes. The NORs are located on the short arm of a submetacentric pair (pair 4) in D. maculatus and in intersticial position on a medium acrocentric (pair 21) in the E. pisonis. Meiotic analyses carried out on D. maculatus and E. pisonis showed a modal value of 23 in both MI and in MII. Comparison with cytogenetic data of Mexican populations (D. maculatus, $34 \mathrm{~m}-\mathrm{sm}+12 \mathrm{st}-\mathrm{a}$; E. piso$n i s, 2 \mathrm{~m}-\mathrm{sm}+42 \mathrm{st}-\mathrm{a})$ indicated that the karyotypical changes among the populations from Northeastern Brazil and the Mexican coast are mainly due to pericentric inversion, although translocations, fission and fusion are involved in the karyotypic diversification of the group. The differences observed among the karyotype macrostructure of South and Central American forms suggest the existence of distinct species in these two regions.
\end{abstract}

Key words Intraspecific karyotypical diversity, Eleotridae.

The Eleotridae family consists of 35 genera and 150 species distributed in freshwaters/brackish waters, estuaries or shores of tropical and subtropical regions (Nelson 1994). It is represented by a few species in the east of South America that inhabit the lower courses of coastal rivers. Two of these species, Dormitator maculatus and Eleotris pisonis, are widely distributed geographically, stretching from the Gulf of Mexico and the Bahamas to the south of Brazil (Menezes and Figueiredo 1985).

Cytogenetical data for Eleotridae family are scarce (Arai and Sawada 1974, Krysanov and Elovenko 1981). The chromosome analyses already performed seem that a diploid value of 46 chromosomes is a basal characteristic for the group. However, some exceptions have been observed regarding the chromosome formulas in the different genera.

The Dormitator genus has representatives on both the Atlantic (D. maculatus) and Pacific (D. latifrons) sides of Central America. In spite of the barrier that separates them, cytogenetics analyses have revealed that their karyotypic macrostructures are still quite similar $(2 n=46,34 \mathrm{~m} / \mathrm{sm}+12 \mathrm{st} / \mathrm{a})$ (Uribe-Alcocer 1985, Uribe-Alcocer and Ramirez-Scamilla 1989). However, the karyotypes of the species D. maculatus and E. pisonis of the Mexican coast (Uribe-Alcocer and Ramirez-Scamilla 1989, Montes-Perez 1981) present considerable divergences for the diploid number and chromosome formulas.

In the present study, chromosome banding ( $\mathrm{C}$ banding and Ag-NORs) and also meiotic analy-

* Corresponding author, e-mail: molinawf@yahoo.com.br 
ses was used in D. maculatus in E. pisonis to establish phylogenetic relationships among these genera and to ascertain possible chromosomal diversification among geographically isolated populations of America.

\section{Material and methods}

Dormitator maculatus ( 9 males and 3 females) and Eleotris pisonis specimens ( 2 males and 3 females) were collected, in sympatry and syntopy at $5 \mathrm{~km}$ from the mouth of the Pium River, Rio Grande do Norte state, Northeastern Brazil.

Mitotic stimulation (Lee and Elder 1980) was used for to increase the metaphase figures, obtained according to Gold et al. (1990). Gonadal tissue samples from males were utilized for meiotic analyses (Kligerman and Bloom 1977). C banding (Sumner 1972) and nucleolar organizing regions (Ag-NORs) analyses (Howell and Black 1980) were established to both species. Karyotypic formula was determinate according with the Levan et al. (1964) chromosome classification.

\section{Results}

Both species presented $2 n=46$ with striking differences for the chromosome formulas. $D$. maculatus species presented a karyotype with many two-armed chromosomes, $40 \mathrm{~m} / \mathrm{sm}+6 \mathrm{st}$, $\mathrm{NF}=92$. The NORs are located on a single submetacentric pair (pair 4) showing telomeric ribosomal sites on the short arm (Fig. 1a). C-banding performed on D. maculatus showed heterochromatic segments, mainly distributed in centromeric position (Fig. 1b), without numerical or structural chromosome heteromorphisms sex related.

E. pisonis showed a karyotype presenting 46 acrocentric chromosomes. NORs sites were located on pericentromeric position on the long arms of the pair 21 (Fig. 2a). In this species, C-banding revealed heterochromatic blocks located on the centromeric and pericentromeric regions (Fig. $2 b$ ).

The meiotic analyses in the two species presented spermatogonials metaphases with $2 n=46$ chromosomes, 23 bivalents in MI (metaphase I) and 23 chromosomes in MII (Fig. 3a-f).

\section{Discussion}

Many cytogenetical analyses have shown that fish populations, although grouped taxonomically within the same nominal species, have reached such a degree of chromosome differentiation that they could be considered as distinct species (Moreira-Filho and Bertollo 1991).

Factors such as inversions, translocations and the heterochromatin process, involving mainly the sex chromosomes, are important agents of post-zygotic barriers that impede introgression and consequently reinforce growing stages of differentiation up to the species level.

The sample of $E$. pisonis of the Pium river presented a karyotype with $2 n=46$ acrocentric chromosomes $(\mathrm{NF}=46)$. Similar karyotypes were also observed for others species of this genus, such as E. acanthopomus (Arai and Sawada 1974) and E. muralis (Khuda-Bukhsh and Nayak 1990).

The modal diploid number $(2 n=46)$ found in 13 Eleotridae species previously studied, is also common in the Gobiidae group (Caputo et al. 1996, Caputo et al. 1997), with close phylogenetic relationship with the Eleotridae. This diploid number shows it to be a symplesiomorphic trait in Eleotridae, indicating a numerical reduction in the chromosomes compared to the basal karyotype of the Perciformes $(2 n=48)$. However, the results for E. pisonis from the northeastern region of Brazil showed that they were significantly distant from those of the Mexican populations of the same species that presented a numerically and structurally differentiated karyotypic formula showing $2 \mathrm{~m}-\mathrm{sm}+42 \mathrm{st}-\mathrm{a}$ and $\mathrm{NF}=46$ (Uribe-Alcocer and Diaz-Jaimes 1996). 


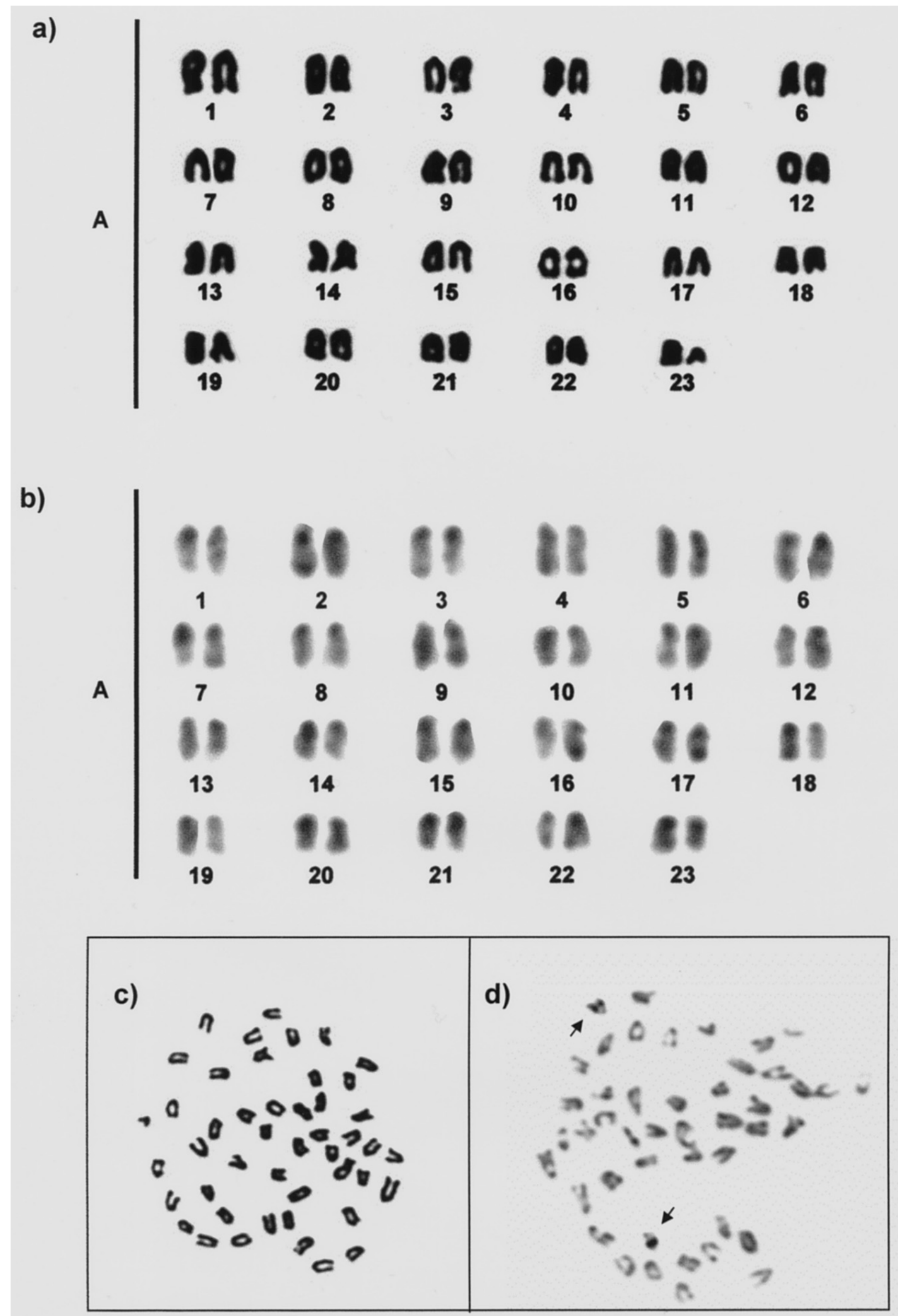

Fig. 1. a) Eleotris pisonis karyotype stained with Giemsa, $2 n=46 a$. b) C-banding. c) somatic metaphase. d) NOR-bearing chromosomes (pair 21). 


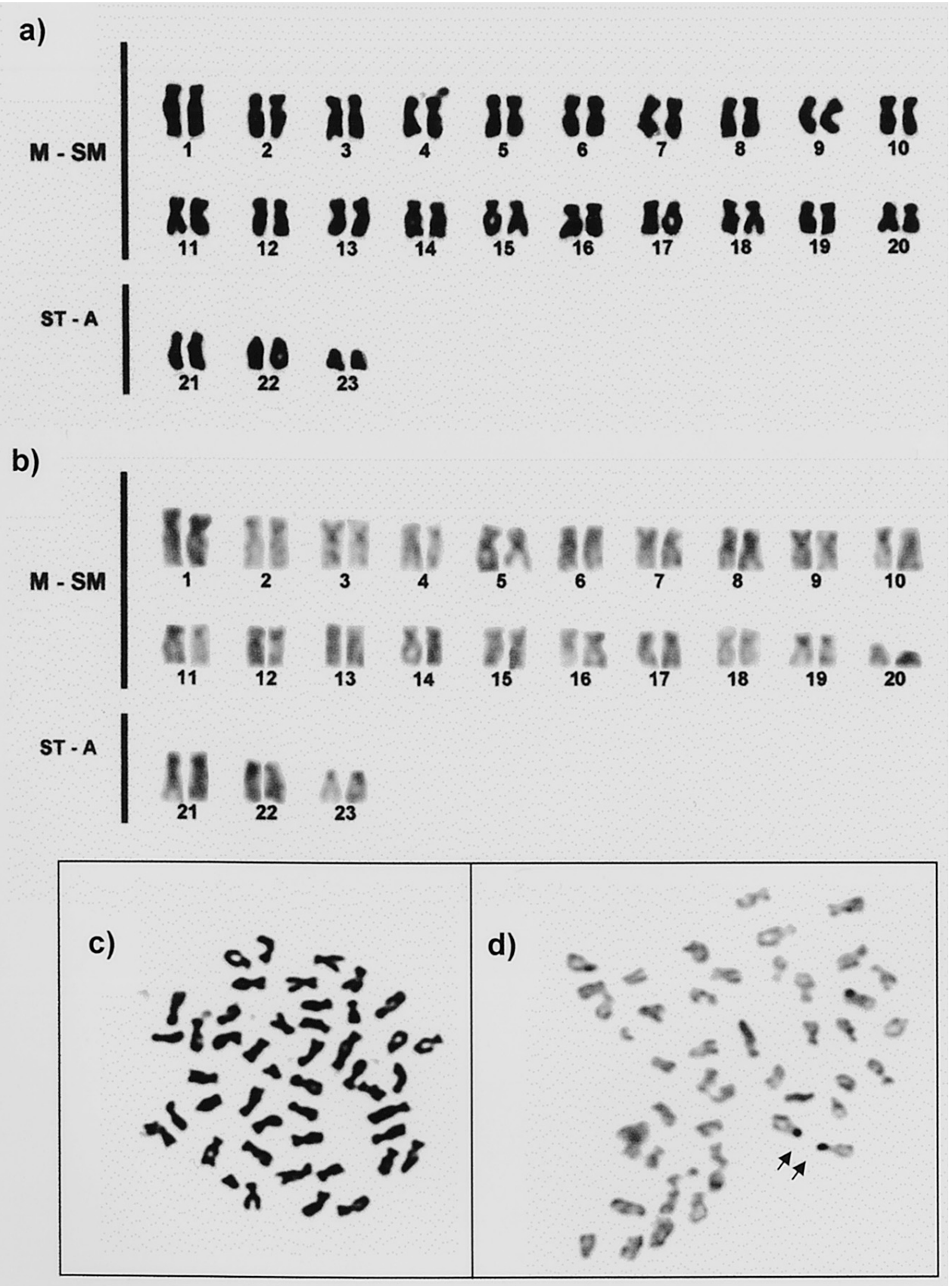

Fig. 2. Karyotype of Dormitator maculatus by a) conventional staining, $2 n=46$. b) C-banding. c) somatic metaphase. d) Arrows indicate NOR-bearing chromosomes (pair 4). 


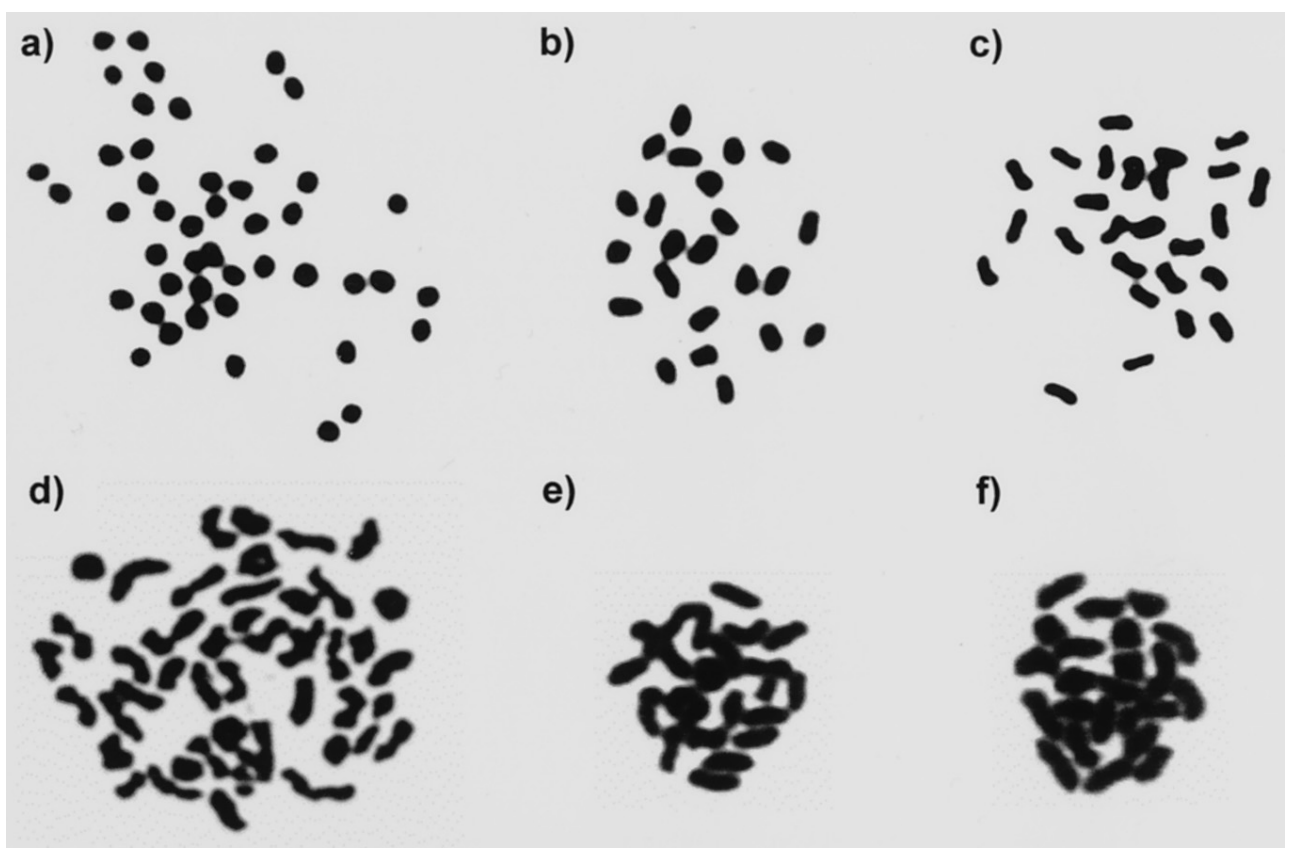

Fig. 3. Meiotic metaphases. a-c) Eleotris pisonis. d-f) Dormitator maculatus. From right to left, spermatogonial metaphase $(2 n=46)$, metaphase I ( 23 bivalents) and metaphase II ( 23 chromosomes), respectively.

The vast distribution area (north of the United States to the south of Brazil) of the Eleotris pisonis species and the natural geographic barriers provided by the estuary regions that flow into the Atlantic, including the mouths of the Orinoco and Amazon Rivers, make maintenance of gene flow unlikely between the extremes of distribution of this species, similarly to others Atlantic species (Briggs 1974, Floeter and Gasparini 2000). Thus it appears that causer events for population stratification, in this case, bring about the establishment of biologically distinct species that are still grouped as a single nominal species. Apparently the karyotype of the Mexican populations is more derived than that the South American forms, because of the presence of a biarmed pair, derived from centric fusion. In this genus, other events, such as chromosome fission, act in the chromosome evolution of the genus, bearing in mind that the E. picta karyotype, $2 n=52$ and NF $=52$ (Uribe-Alcocer and Diaz-Jaimes 1996), may have originated by this process.

The D. maculatus population of Pium river presented a karyotype with $2 n=46,40 \mathrm{~m}-\mathrm{sm}+6$ st-a and $\mathrm{NF}=86$, and no indication was observed of sex chromosome heteromorphism. In contrast, the population from the Itinga River in Mongaguá, in Southeastern Brazil, showed $2 n=46$, $40 \mathrm{~m} / \mathrm{sm}+6 \mathrm{st} / \mathrm{a}$ in the females and $41 \mathrm{~m} / \mathrm{sm}+5 \mathrm{st} / \mathrm{a}$ in the males, indicating the possible presence of a $\mathrm{XX} / \mathrm{XY}$ sex chromosomes (Oliveira and Almeida-Toledo 1985), where the males presented one biarmed chromosome (Y) not found in the females. Cytogenetical studies carried out on this species in Mexico showed a karyotype consisting of $34 \mathrm{~m} / \mathrm{sm}+12 \mathrm{st} / \mathrm{a}$ and $\mathrm{NF}=80$ (Maldonado-Monroy et al. 1985). These results showed numeric conservatism among the Brazilian populations and the Mexican population, differing with regards to the karyotypic macrostructure.

Meiotic analysis $(\mathrm{MI}=23$ and $\mathrm{MII}=46)$ in these species corroborated with the diploid numbers, no showing evidence of sex chromosomes.

The Eleotrid sleeper Gobiomorphus breviceps, from New Zealand, shows variations in the colors of different populations seemed to indicate population stratifications and reduced genetic flow (Maldonado-Monroy et al. 1985). These striking karyotypic modifications can be attributed to peri- 
centric inversion, with evident modification in the fundamental number between the 2 forms observed. In addition, such inversion process seems to play an active role in the karyotypic evolution of Oxyeleotris marmorata, on the islands of Java, Sumatra and Kalimantan/Borneo (considered as the Indo-Malaysian region). O. marmorata presented a karyotype of $2 n=46(42 \mathrm{~m}+4 \mathrm{sm}, \mathrm{NF}=92)$, with an extra metacentric chromosomes in polymorphic condition in the Java population (Masagca 2000). Also in this case, geographic isolation seems to have been decisive in the karyotypic differentiation of the populations. Thus the cytogenetic analyses, as for E. pisonis, indicated the need for taxonomic revision in $D$. maculatus since it seems to harbor biologically different forms.

The results of $\mathrm{C}$ banding in the D. maculatus and E. pisonis, did not show differences among karyotypes of males and females. Heterochromatic blocks could be observed located in centromeric and/telomeric position, with some pairs, in the first species, showing smaller totally heterochromatic arms. Thus it is possible that heterochromatin processes may play a part in the karyotypic differentiation observed among the geographically distinct populations from the Pium river (Northeastern Brazil) (present paper), Itinga river (Southeastern Brazil) (Oliveira and Almeida-Toledo 1985) and from the Gulf of Mexico (Maldonado-Monroy et al. 1985).

NORs sites are localized on a unique pair in the two species, similarly to others Perciformes groups (Molina 2000). The lack of data on other species of this family does not permit inference on the constancy of this pattern for the group.

Thus it seems evident that several kinds of rearrangements such as pericentric inversion, fusions and fission added to heterochromatin processes play an active role in the chromosome diversity observed among Eleotridae samples from South and Central America, strongly suggesting that they seem biologically cryptic forms and not more populations of a same species.

\section{Acknowledgements}

This work was supported by Coordenação de Aperfeiçoamento de Pessoal Docente do Ensino Superior (CAPES).

\section{References}

Arai, R. and Sawada, Y. 1974. Chromosomes of Japanese gobioid fishes (1). Bull. Natl. Sci. Mus. Tokyo 17: 97-102. Briggs, J. C. 1974. Marine Zoogeography. McGraw-Hill, New York.

Caputo, V., Vitturi, G., Odierna, G., Cano, J., Olmo, E. and Colomba, M. S. 1996. Characterization of mitotic chromosomes in the Gobiid fish Zosterisessor ophiocephalus (Pallas, 1811) (Perciformes, Gobiidae). Biol. Zent. Bl. 115: 328336.

—, Marchegiani, F., Sorice, M. and Olmo, E. 1997. Heterochromatin heterogeneity and chromosome variability in four species of gobiid fishes (Perciformes: Gobiidae). Cytogenet. Cell Genet. 79: 266-271.

Floeter, S. R. and Gasparini, J. L. 2000. The southwestern Atlantic reef fish fauna: Composition and zoogeographic patterns. J. Fish Biol. 56: 1099-1114.

Gold, J. R., Li, C., Shipley, N. S. and Powers, P. K. 1990. Improved methods for working with fish chromosomes with a review of metaphase chromosome banding. J. Fish Biol. 37: 563-575.

Hamilton, W. and Poulin, R. 1999. Female preference and male nuptial colouration in the freshwater fish Gobiomorphus breviceps: Geographic variation among populations. Canadian J. Zool. 77: 463-469.

Howell, W. M. and Black, A. 1980. Controlled silver staining of nucleolus organizer regions with protective colloidal developer: 1-step method. Experientia 36: 1014-1015.

Khuda-Bukhsh, A. R. and Nayak, K. 1990. Karyotypic studies in six species of brackish water fishes from India. Kromosomo 2: 1955-1960.

Kligerman, A. D. and Bloom, S. E. 1977. Rapid chromosomes preparations from solid tussues of fishes. J. Fisheries Res. Board Canada 34: 266-269.

Krysanov, E. Y. and Elovenko, V. N. 1981. Structural peculiarities of the karyotype of the Amur "sleeper" Perccottus giehnii (Eleotridae) in different parts of Its range. J. Ichthyol. 21: 124-127.

Lee, M. R. and Elder, F. F. B. 1980. Yeast stimulation of bone marrow mitosis for cytogenetic investigations. Cytogenet. 
Cell Genet. 26: 36-40.

Levan, A., Fredga, K. and Sandberg, A. A. 1964. Nomenclature for centromeric position on chromosomes. Hereditas 52: 201-220.

Maldonado Monroy, M. C., Uribe-Alcocer, M., Arreguin Spinosa, J. and Castro Perez, A. 1985. Karyotypical studies on Dormitator maculatus Bloch and Gobiomorus dormitor Lacepede (Gobiidae Perciformes). Cytologia 50: 15-21.

Masagca, J. T. 2000. Karyology of the Southeast Asian marble sleeper, Oxyeleotris marmorata Bleeker 1852 (Teleostei: Eleotridae). Asia Life Sci. 9: 181-188.

Menezes, N. A. and Figueiredo, J. L. 1985. Manual de Peixes Marinhos do Sudeste do Brasil. V. Teleostei (4). Museu de Zoologia. Universidade de São Paulo.

Molina, W. F. 2000. Análise da diversidade genética em Pomacentridae (Pisces, Perciformes) utilizando métodos combinados de citogenética, morfometria e marcadores moleculares. Ph.D. Thesis, Universidade Federal de São Carlos, $164 \mathrm{p}$.

Montes-Pérez, R. 1981. Estudios citogéneticos em Eleotris pisonis (Gobiidae, Perciformes). Tesis professional, Faculdad de Ciências. Univ. Nal. Autom. México.

Moreira Filho, O. and Bertollo, L. A. C. 1991. Astyanax scabripinnis (Pisces, Characidae): A species complex. Rev. Brasil. Genet. 14: 331-357.

Nelson, J. S. 1994. Fishes of the World, 3rd ed. John Wiley \& Sons, New York.

Oliveira, C. and Almeida Toledo, L. F. 1985. Caracterização cromossômica e regiões organizadoras do nucléolo de Dormitator maculatus (Bloch, 1790) (Perciformes-Eleotrididae). In: XII Congresso Brasileiro de Zoologia, Campinas, SP. p. 174.

Sumner, A. T. 1972. A simple technique for demonstrating centromeric heterochromatin. Exp. Cell 25: 304-306.

Uribe-Alcocer, M. 1985. Antecedentes y perspectivas nacionales de los estudios geneticos em peces. In: Conferencia Internacional-Uso y preservación de los recursos biológicos marinos y de zonas áridas. La Paz.

— and Ramírez-Escamilla, A. 1989. Comparación citogenética entre las especies del genero Dormitator (Pisces, Gobiidae) An. Inst. Cienc. del Mar y Limnol. Univ. Nat. México 16: 75-80.

— and Diaz-Jaimes, P. 1996. Chromosome complements of Gobionellus microdon and Eleotris picta collected in Mexico. J. Fish Biol. 48: 796-798. 